American Journal of Agricultural and Biological Sciences 4 (3): 215-223, 2009

ISSN 1557-4989

(C) 2009 Science Publications

\title{
Effect of Super Absorbent Application on Antioxidant Enzyme Activities in Canola (Brassica napus L.) Cultivars under Water Stress Conditions
}

\author{
${ }^{1}$ H.R. Tohidi-Moghadam, ${ }^{2}$ A.H. Shirani-Rad, ${ }^{3}$ G. Nour-Mohammadi, \\ ${ }^{4}$ D. Habibi and ${ }^{5} \mathrm{M}$. Mashhadi-Akbar-Boojar \\ ${ }^{1}$ Department Agronomy and Plant Breeding, Science and Research Branch, \\ Islamic Azad University, Tehran, Iran \\ ${ }^{2}$ Department of Crop Physiology, Seed and Plant Improvement Institute, Karaj, Iran \\ ${ }^{3}$ Department of Crop Ecology, Department of Agronomy and Plant Breeding, \\ Science and Research Branch, Islamic Azad University, Tehran, Iran \\ ${ }^{4}$ Department of Crop Physiology, Department of Agronomy and Plant Breeding, \\ Karaj Branch, Islamic Azad University, Karaj, Iran \\ ${ }^{5}$ Department of Biochemistry, Tarbiat moallem Tehran University, Tehran, Iran
}

\begin{abstract}
Problem statement: Drought stress significantly limits Canola (Brassica napus L.) growth and crop productivity. Hence, efficient management of soil moisture and study metabolic changes which occur in response to drought is important for agricultural production of this Crop. Approach: For a better understanding of drought tolerance mechanisms and improving soil water content management strategies, an experiment was laid out in a randomized complete block design with factorial spilt arrangement with tree replications. Results: Irrigation strategy and super absorbent application were allotted to main plots. Irrigation strategy had two levels: $80 \%$ of evaporation as control $\left(\mathrm{I}_{1}\right)$, drought stress started from flowering stage $\left(\mathrm{I}_{2}\right)$ Application of super absorbent had two levels: Non-application of super absorbent as control $\left(\mathrm{S}_{1}\right)$, application of super absorbent with $7 \%$ concentration. Cultivars $\left(\operatorname{Rgs003}\left(\mathrm{V}_{1}\right)\right.$, Sarigol $\left(\mathrm{V}_{2}\right)$, Option500 $\left(\mathrm{V}_{3}\right)$, Hyola401 $\left(\mathrm{V}_{4}\right)$, Hyola330 $\left(\mathrm{V}_{5}\right)$, Hyola420 $\left(\mathrm{V}_{6}\right)$ were allotted to sub plots. Plants under water deficit stress and application of super absorbent showed a significant increase and decrease, respectively, in SOD, CAT and GPX activities in leaves compared with control plants. In this context, plants with higher levels of antioxidants showed higher resistance to these stress conditions and higher yield and dry matter allocation to grain filling process i.e. harvest index. Conclusion/Recommendations: Our results suggested that drought stress leads to production of oxygen radicals, which results in increased lipid peroxidation and oxidative stress in the plant. In conclusion of present study, Application of super absorbent polymer could reserve different amounts of water in itself and so increases the soil ability of water storing and preserving and at last in water deficiency, produce plant water need and approve its growth under postanthesis water deficiency.
\end{abstract}

Key words: Canola, super absorbent, drought stress, agronomic characters, antioxidant enzymes

\section{INTRODUCTION}

Drought stress significantly limits plant growth and crop productivity. However in certain tolerant/adaptable crop plants morphological and metabolic changes occur in response to drought, which contribute towards adaptation to such unavoidable environmental constraints $^{[8,53]}$. Efficient management of soil moisture is important for agricultural production in the light of scarce water resources. Soil conditioners, both natural and synthetic, contribute significantly to provide a reservoir of soil water to plants on demand in the upper layers of the soil where the root systems normally develop. These polymeric organic materials and hydro gels apart from improving the soil physical properties, also serve as buffers against temporary drought stress and reduce the risk of plant failure during establishment $^{[17,31]}$. This is achieved by means of reduction of evaporation through restricted movement of water from the sub-surface to the surface layer ${ }^{[41]}$.

Corresponding Author: H.R. Tohidi-Moghadam, Islamic Azad University Science and Research Branch, Tehran, Iran 
Brassica oilseed species now hold the third position among the oilseed crops and are an important source of vegetable oil ${ }^{[5]}$. Drought stress invariably leads to oxidative stress in the plant cell due to higher leakage of electrons towards $\mathrm{O}_{2}$ during photosynthetic and respiratory processes leading to enhancement in Reactive Oxygen Species (ROS) generation ${ }^{[3]}$. The ROS such as $\mathrm{O}_{2}^{-}, \mathrm{H}_{2} \mathrm{O}_{2}$ and $\mathrm{OH}$ radicals, can directly attack membrane lipids, inactive metabolic enzymes and damage the nucleic acids leading to cell death ${ }^{[37]}$. The reaction of plants to water stress differ significantly at various organizational levels depending upon intensity and duration of stress as well as plant species and its stage of development ${ }^{[14]}$. Mechanisms of active oxygen species detoxification exist in all the plants and include activation of enzymatic (superoxide dismuatase, catalase, ascorbat peroxidase, peroxidase, glutathione reductase $\mathrm{e}^{[32]}$. The degree to which the activities of antioxidant enzymes and the amount of antioxidants are elevated under drought stress is extremely variable among several plant species ${ }^{[53]}$ and even between the two cultivars of the same species ${ }^{[7]}$. However, under conditions of environmental stress, production of ROS can increase and endogenous protective activity may then become inadequate. Various associations between water stress and endogenous levels of water-soluble antioxidants have been described ${ }^{[53]}$. Environmental stresses including drought and temperature affect nearly every aspect of the physiology and biochemistry of plants and significantly diminish yield. Many arid and semi-arid regions in the world contain soils and water resources that are too saline for most of the common economic crops, which affect plants through osmotic effects, ion specific effects and oxidative stress ${ }^{[39,43]}$. Much of the injury to plants exposed to stress is connected with oxidative damage at the cellular level $^{[22]}$. If there is a serious imbalance in any cell compartment between the production of Reactive Oxygen Species (ROS) and antioxidant defense, oxidative stress and damage occurs ${ }^{[37]}$. Even under normal growth conditions, low amounts of ROS such as superoxide radical $\left(\mathrm{O}_{2}^{-}\right)$, hydrogen peroxide $\left(\mathrm{H}_{2} \mathrm{O}_{2}\right)$, hydroxyl radical $\left(\mathrm{OH}\right.$.) and singlet oxygen $\left(1 \mathrm{O}_{2}\right)$ are metabolic byproducts of plant cells ${ }^{[15]}$. Plants have developed the scavenging mechanism of ROS categorized as enzymatic and non-enzymatic ${ }^{[44,18]}$. When ROS increases, chain reactions start, in which Superoxide Dismutase (SOD) catalyzes the dismutation of $\mathrm{O}_{2}{ }^{-}$radicals to molecular $\mathrm{O}_{2}$ and $\mathrm{H}_{2} \mathrm{O}_{2}{ }^{[36]}$. The $\mathrm{H}_{2} \mathrm{O}_{2}$ is then detoxified in the ascorbate-glutathione cycle ${ }^{[4,37]}$ (which involves the oxidation and re-reduction of ascorbate and glutathione through the Ascorbate Peroxidase (APX) and Glutathione Reductase (GR) action $^{[21,38]}$. Drought stress induces cellular accumulation of ROS which can damage membrane lipids, proteins and nucleic acids ${ }^{[1,7,27-29,35]}$ A correlation between the antioxidant capacity and $\mathrm{NaCl}$ tolerance has been demonstrated in some plant species ${ }^{[19,25,28]}$. Several studies have pointed out that drought-tolerant species increased their antioxidant enzyme activities and antioxidant contents in response to drought treatment, whereas drought-sensitive species failed to do $\mathrm{so}^{[18,49]}$. To be able to endure oxidative damage under (unfavorable conditions such as high/low temperatures, water deficit and salinity, plants must possess efficient antioxidant system ${ }^{[46]}$. In addition, plants are subjected to the interaction of two or more environmental stress factors under natural conditions and many studies have been carried out to study the effects of these stress factors on plant metabolism separately. Therefore, the aim of the study was to investigate the effect of long-term drought stress and temperature interaction on antioxidant enzyme activities (APX, GR and POD) in the canola plants Therefore, the primary objective of the present investigation was to examine the effect of drought stress on the activities of different antioxidant enzymes and biochemical exchanges in leaves of canola. The research was aimed also whether a super absorbent polymer supply to plant might be a strategy for increasing the drought tolerance.

\section{MATERIALS AND METHODS}

The experiment was carried out in Seed and Plant Improvement Institute, Kraraj, Iran during 2007-2008. The site is located at $35^{\circ} 59^{\prime} \mathrm{N}$ latitude, $50^{\circ} 75^{\prime} \mathrm{E}$ longitudes and an altitude of $151 \mathrm{~m}$ above the sea level. This region has a semi-arid climate $(354 \mathrm{~mm}$ rainfall yearly). The soil of experimental site was clay loam with a clay type of montmorillionite, low in nitrogen (0.06$0.07 \%)$, low in organic matter $(0.56-060)$ and alkaline in reaction with a $\mathrm{PH}$ of 7.9 and $\mathrm{Ec}=0.66 \mathrm{dS} \mathrm{m}^{-1}$. The soil texture is sand loam with $10 \%$ neutralizing substances. Experiment was laid out in a randomized complete block design with factorial spilt arrangement with tree replications. Irrigation strategy and super absorbent application were allotted to main plots. Irrigation strategy had two levels: $80 \%$ of evaporation as control $\left(\mathrm{I}_{1}\right)$, drought stress started from flowering stage $\left(\mathrm{I}_{2}\right)$ Application of super absorbent had two levels: Nonapplication of super absorbent as control $\left(S_{1}\right)$, application of super absorbent with $7 \%$ concentration. cultivars $\left(\operatorname{Rgs003}\left(\mathrm{V}_{1}\right)\right.$, Sarigol $\left(\mathrm{V}_{2}\right)$, Option500 $\left(\mathrm{V}_{3}\right)$, Hyola401 $\left(\mathrm{V}_{4}\right)$, Hyola330 $\left(\mathrm{V}_{5}\right)$, Hyola420 $\left(\mathrm{V}_{6}\right)$ were allotted to sub plots. Then $7 \%$ concentration of super 
absorbent for each plot was noticed. After calculation, super absorbents were poured in necessary amount on each pail separately and sufficient water was applied. Then 30 min was left till super absorbents absorb water completely and then were poured on the whole plot monotonously and accurately. After settling each plot was covered with soil. Irrigation of control group was done with seven days apart. Measured parameters where Grain yield, harvest index, the amount of biochemical characters (super oxide dismuatase, catalase and glutathione per oxidase.

Sampling: After drought stress treatment, three leaves of each plant were removed. The samples were washed and then frozen in liquid $\mathrm{N}_{2}$ and then stored at $-80^{\circ} \mathrm{C}$ pending biochemical analysis.

Preparation of extracts: Leaf sample was homogenized in a mortar and pestle with $3 \mathrm{~mL}$ ice-cold extraction buffer (25 mM sodium phosphate, $\mathrm{pH} 7.8$ ). The homogenate was centrifuged at $18000 \mathrm{~g}$ for $30 \mathrm{~min}$ at $48^{\circ} \mathrm{C}$ and then supernatant was filtered through paper. The supernatant fraction was used as a crude extract for the assay of enzyme activity. All operations were carried out at $48^{\circ} \mathrm{C}$.

Assay of antioxidant enzymes: Catalase activity was estimated by the method of Cakmak and Horst ${ }^{[13]}$. The reaction mixture contained 100 crude enzyme extract, $500 \mu \mathrm{L} 10 \mathrm{mM} \mathrm{H} \mathrm{H}_{2} \mathrm{O}_{2}$ and $1400 \mu \mathrm{L} 25 \mathrm{mM}$ sodium phosphate buffer. The decrease in the absorbance at $240 \mathrm{~nm}$ was recorded for $1 \mathrm{~min}$ by spectrophotometer, model Cintra 6 GBC (GBC Scientific Equipment, Dandenong, Victoria, Australia). CAT activity of the extract was expressed as CAT units per milligram of PROT. Superoxide dismutase activity was determined with the reaction mixture contained $100 \mu \mathrm{L} 1 \mu \mathrm{M}$ riboflavin, $100 \mu \mathrm{L} 12 \mathrm{mM}$ L-methionine, $100 \mu \mathrm{L}$ $0.1 \mathrm{mM}$ EDTA (pH 7.8), $100 \mu \mathrm{L} 50 \mathrm{mM} \mathrm{Na} 2 \mathrm{CO}_{3}(\mathrm{pH}$ 10.2) and $100 \mu \mathrm{L} 75 \mu \mathrm{M}$ Nitroblue Tetrazolium (NBT) in $2300 \mu \mathrm{L} 25 \mathrm{mM}$ sodium phosphate buffer ( $\mathrm{pH} 6.8$ ), $200 \mu \mathrm{L}$ crude enzyme extract in a final volume of $3 \mathrm{~mL}$. SOD activity was assayed by measuring the ability of the enzyme extract to inhibit the photochemical reduction of NBT glass test tubes containing the mixture were illuminated with a fluorescent lamp $(120 \mathrm{~W})$; identical tubes that were not illuminated served as blanks. After illumination for $15 \mathrm{~min}$, the absorbance was measured at $560 \mathrm{~nm}$. One unit of SOD was defined as the amount of enzyme activity that was able to inhibit by $50 \%$ the photo reduction of NBT to blue formazan. The SOD activity of the extract was expressed as SOD units per milligram of PROT. Peroxidase activity was determined by the oxidation of guaiacol in the presence of $\mathrm{H}_{2} \mathrm{O}_{2}$. The increase in absorbance was recorded at $470 \mathrm{~nm}^{[24]}$. The reaction mixture contained $100 \mu \mathrm{L}$ crude enzyme, $500 \mu \mathrm{L} \mathrm{H}_{2} \mathrm{O}_{2} 5 \mathrm{mM}, 500 \mu \mathrm{L}$ guaiacol $28 \mathrm{mM}$ and $1900 \mu \mathrm{L}$ potassium phosphate buffer $60 \mathrm{mM}$ (pH 6.1). POX activity of the extract was expressed as POX units per mg.

Statistical analysis: All data were analyzed using SAS software Each treatment was analyzed in three replication. When ANOVA showed significant treatment effects. Duncan's multiple range test was applied to compare the means at $\mathrm{p}<0.05^{[54]}$.

\section{RESULTS}

The results showed that water deficit stress affected all parameters measured; the effect of three-way interaction between irrigation $\times$ super absorbent $\times$ varieties was significant for all variables except SOD and GPX activities in both years (Table 1).

Results showed a significant difference between irrigation treatments, concentration of super absorbent and varieties studied of yielding and measured biochemical characteristic. As it was shown, water deficit stress decreases yield and its components, increases biochemical characters and in other hand, using 7\% super absorbent in field situation increases agricultural characters, also field results show that in water deficit stress and non application of super absorbent, the best record in this exam belongs to Hyola330 because antioxidant enzymes increased in this condition in Hyola330 variety and the most sensitive record was Sarigol variety because antioxidant enzymes decrease in this condition. Plants under water deficit stress showed decrease in yield and harvest index parameters.

Also results three-way interaction between irrigation $\times$ super absorbent $\times$ variety show that in water deficit stress and application of super absorbent could cause of improvement in yield and harvest index (Table 2). However, results showed that the highest yield and harvest index were obtained in Option500 variety. On the other hand study of material effects of interaction irrigation with polymer showed that in both conditions (normal and stress) this polymer has increased yield rate in every variety but yield and harvest index was increased in 2008 year. Natural rainfall varied between the 2007 and 2008 seasons (Total rainfall during the growing season was $149.1 \mathrm{~mm}$ in 2007 and $186.6 \mathrm{~mm}$ in 2008). In addition to greater rainfall in 2007, there was also a more uniform rain distribution compared to 2008. 
Am. J. Agri. \& Biol. Sci., 4 (3): 215-223, 2009

Table 1: Analysis of variance for experimental triets

\begin{tabular}{|c|c|c|c|c|c|c|}
\hline \multirow[b]{2}{*}{ Treatment } & \multirow[b]{2}{*}{$\mathrm{df}$} & \multicolumn{2}{|r|}{ MS } & \multirow[b]{2}{*}{$\begin{array}{l}\text { Superoxide } \\
\text { dismuatase } \\
\text { enzyme }\end{array}$} & \multirow[b]{2}{*}{$\begin{array}{l}\text { Catalase } \\
\text { enzyme }\end{array}$} & \multirow[b]{2}{*}{$\begin{array}{l}\text { Peroxidase } \\
\text { glutathione } \\
\text { enzyme }\end{array}$} \\
\hline & & Yield & Harvest index & & & \\
\hline Year & 1 & $26117465.78 * *$ & $142.291000^{* *}$ & $470367.361 * *$ & $1254.222 \mathrm{~ns}$ & $16.660 \mathrm{~ns}$ \\
\hline Error & 4 & 530869.0300 & 0.000100 & 9200.174 & 542.138 & 26.759 \\
\hline Irrigation & 1 & $63670159.41 * *$ & $146.872000^{* *}$ & $7592780.250 * *$ & $22199.013 * *$ & $1993.324 * *$ \\
\hline Super absorbent & 1 & $62248812.54 * *$ & $137.250000^{* *}$ & $202200.111^{* *}$ & $922.843 * *$ & $324.720 * *$ \\
\hline Irrigation* super absorbent & 1 & $12858260.46^{* *}$ & $1223.373000^{* *}$ & $215605.444^{* *}$ & $1175.346^{* *}$ & $113.777 * *$ \\
\hline Year* irrigation & 1 & $2102910.85^{* *}$ & $0.187000^{* *}$ & $4.694 \mathrm{~ns}$ & $3.737 \mathrm{~ns}$ & $3.770 * *$ \\
\hline Year* super absorbent & 1 & $2069593.94 * *$ & $0.175000^{* *}$ & $2240.444 n s$ & $2.325 \mathrm{~ns}$ & $0.691 \mathrm{~ns}$ \\
\hline Year* super absorbent $*$ irrigation & 1 & $419979.60^{* *}$ & $1.559000^{* *}$ & $18.778 \mathrm{~ns}$ & $10.112 \mathrm{~ns}$ & $0.140 \mathrm{~ns}$ \\
\hline Error & 12 & $28979.07 * *$ & 0.000100 & 6081.961 & 3.337 & 0.354 \\
\hline Variety & 5 & $6499892.94 * *$ & $2850.732310 * *$ & $654781.611 * *$ & $751.127 * *$ & $91.533^{* *}$ \\
\hline Irrigation* variety & 5 & $1388768.81^{* *}$ & $77.728760 * *$ & $527706.100^{* * *}$ & $423.493 * *$ & $52.024 * *$ \\
\hline Super absorbent* variety & 5 & $1381621.11^{* * *}$ & $73.261030^{* *}$ & $9602.128 \mathrm{~ns}$ & $434.606^{* *}$ & $2.813^{* *} *$ \\
\hline Year* variety & 5 & $225859.71 * *$ & $3.637130 * *$ & $7494.944 n s$ & $8.302 * *$ & $0.025 \mathrm{~ns}$ \\
\hline Irrigation* super absorbent* variety & 5 & $4582683.29 * *$ & $135.090230 * *$ & $13554.728 \mathrm{~ns}$ & $144.352 * *$ & $0.760 * *$ \\
\hline Year* variety* irrigation & 5 & $48946.61^{* *}$ & $0.098980^{* *}$ & $8953.144 \mathrm{~ns}$ & $6.112 * *$ & $0.228 * *$ \\
\hline Year* variety* super absorbent & 5 & $50239.94 * *$ & $0.093470^{* *}$ & $8499.794 \mathrm{~ns}$ & $7.755^{* *}$ & $0.362 * *$ \\
\hline Year*variety*superabsorbent* irrigation & 5 & $159016.29 * *$ & $0.172360 * *$ & $8222.661 \mathrm{~ns}$ & $6.330 * *$ & $0.040 \mathrm{~ns}$ \\
\hline Error & 80 & 3188.80 & 0.000100 & 7042.930 & 1.503 & 0.042 \\
\hline Total & 143 & & & & & \\
\hline $\mathrm{CV}$ & & 2.4200 & 0.038000 & 5.480 & 1.190 & 1.040 \\
\hline
\end{tabular}

ns, *: and **: Non significant and significant at the 5 and $1 \%$ levels of probability, respectively

Table 2: Effects of Irrigation Regimes (IR) and super absorbent concentration (SU) and variety (VA) on Yield and harvest index and antioxidant enzymes in canola in 2007 and 2008

\begin{tabular}{|c|c|c|c|c|c|c|c|c|}
\hline & & & $\begin{array}{l}\text { Yield } \\
\left(\mathrm{Kg} \mathrm{ha}^{-1}\right) 2007\end{array}$ & $\begin{array}{l}\text { Yield } \\
\left(\mathrm{Kg} \mathrm{ha}^{-1}\right) 2008\end{array}$ & $\begin{array}{l}\text { Harvest index } \\
\text { (\%) } 2007\end{array}$ & $\begin{array}{l}\text { Harvest index } \\
\text { (\%) } 2008\end{array}$ & $\begin{array}{l}\text { CAT } \\
\text { (u mg }^{-1} \text { protein) } 2008\end{array}$ & $\begin{array}{l}\text { CAT } \\
\text { (u mg }^{-1} \text { protein) } 2008\end{array}$ \\
\hline$\overline{\mathrm{IR}}$ & SU & VA & & & & & & \\
\hline \multirow[t]{12}{*}{$\mathrm{I}_{1}$} & $S_{1}$ & $\mathrm{~V}_{1}$ & $1419.83 \mathrm{~d}$ & $2058.73 \mathrm{~d}$ & $11.328 \mathrm{f}$ & $12.167 \mathrm{f}$ & $94.966700 \mathrm{~d}$ & $88.79670 \mathrm{c}$ \\
\hline & & $\mathrm{V}_{2}$ & $1312.13 \mathrm{e}$ & $1902.60 \mathrm{e}$ & $12.885 \mathrm{e}$ & $13.839 \mathrm{e}$ & $96.353300 d$ & $89.81000 \mathrm{c}$ \\
\hline & & $\mathrm{V}_{3}$ & $2467.50 \mathrm{a}$ & $3577.90 \mathrm{a}$ & $26.250 \mathrm{~d}$ & $28.195 d$ & $103.356700 \mathrm{~b}$ & $96.84670 \mathrm{~b}$ \\
\hline & & $\mathrm{V}_{4}$ & $1341.47 \mathrm{e}$ & $1945.13 \mathrm{e}$ & $29.025 \mathrm{c}$ & $31.175 \mathrm{c}$ & $101.303300 \mathrm{c}$ & $95.74670 \mathrm{~b}$ \\
\hline & & $\mathrm{V}_{5}$ & $1889.70 b$ & $2728.07 \mathrm{~b}$ & $35.739 a$ & $38.386 a$ & $108.653300 \mathrm{a}$ & $101.76000 \mathrm{a}$ \\
\hline & & $\mathrm{V}_{6}$ & $1538.30 \mathrm{c}$ & $2230.50 \mathrm{c}$ & $29.123 b$ & $31.279 \mathrm{~b}$ & $88.530000 \mathrm{e}$ & $82.01670 \mathrm{~d}$ \\
\hline & $\mathrm{S}_{2}$ & $\mathrm{~V}_{1}$ & $2320.60 \mathrm{~d}$ & $3364.87 \mathrm{~d}$ & $17.560 \mathrm{e}$ & $18.860 \mathrm{e}$ & $93.280000 \mathrm{~b}$ & $96.63330 \mathrm{a}$ \\
\hline & & $\mathrm{V}_{2}$ & $2065.93 \mathrm{e}$ & $2931.87 \mathrm{e}$ & $13.700 \mathrm{f}$ & $14.720 \mathrm{f}$ & $79.363300 \mathrm{e}$ & $72.71330 \mathrm{f}$ \\
\hline & & $\mathrm{V}_{3}$ & $2878.67 \mathrm{c}$ & $4174.07 \mathrm{c}$ & $26.250 \mathrm{~d}$ & $28.190 \mathrm{~d}$ & $96.433300 \mathrm{a}$ & $88.49000 \mathrm{~b}$ \\
\hline & & $\mathrm{V}_{4}$ & $3632.70 \mathrm{~b}$ & $5267.43 b$ & $47.560 \mathrm{a}$ & $51.090 \mathrm{a}$ & $86.270000 \mathrm{~d}$ & $78.84330 \mathrm{~d}$ \\
\hline & & $\mathrm{V}_{5}$ & $4817.40 \mathrm{a}$ & $6985.23 \mathrm{a}$ & $45.550 \mathrm{~b}$ & $48.930 \mathrm{~b}$ & $78.773300 \mathrm{e}$ & $74.65330 \mathrm{e}$ \\
\hline & & $\mathrm{V}_{6}$ & $3642.60 \mathrm{~b}$ & $5281.77 \mathrm{~b}$ & $38.750 \mathrm{c}$ & $41.620 \mathrm{c}$ & $89.676700 \mathrm{c}$ & $83.68670 \mathrm{c}$ \\
\hline \multirow[t]{12}{*}{$\mathrm{I}_{2}$} & $S_{1}$ & $\mathrm{~V}_{1}$ & $1126.07 \mathrm{c}$ & $1632.77 \mathrm{c}$ & $22.116 \mathrm{e}$ & $23.754 \mathrm{e}$ & $120.567000 \mathrm{c}$ & $114.65000 \mathrm{c}$ \\
\hline & & $\mathrm{V}_{2}$ & $644.370 \mathrm{f}$ & 934.330f & $14.956 \mathrm{f}$ & $16.063 \mathrm{f}$ & $101.403000 \mathrm{e}$ & $95.45000 \mathrm{f}$ \\
\hline & & $\mathrm{V}_{3}$ & $832.200 \mathrm{e}$ & $1206.70 \mathrm{e}$ & $24.996 \mathrm{~d}$ & $26.848 d$ & $109.567000 \mathrm{~d}$ & $102.92330 \mathrm{e}$ \\
\hline & & $\mathrm{V}_{4}$ & $1219.10 b$ & $1767.70 \mathrm{~b}$ & $33.686 \mathrm{~b}$ & $36.182 b$ & $127.507000 \mathrm{~b}$ & $121.53670 \mathrm{~b}$ \\
\hline & & $\mathrm{V}_{5}$ & $1527.60 \mathrm{a}$ & $2215.00 \mathrm{a}$ & $41.140 \mathrm{a}$ & $44.188 \mathrm{a}$ & $134.387000 \mathrm{a}$ & $127.78330 \mathrm{a}$ \\
\hline & & $\mathrm{V}_{6}$ & $1028.17 \mathrm{~d}$ & $1490.83 d$ & $29.496 \mathrm{c}$ & $31.680 \mathrm{c}$ & $113.197000 \mathrm{~d}$ & $108.5900 \mathrm{~d}$ \\
\hline & $\mathrm{S}_{2}$ & $\mathrm{~V}_{1}$ & $1417.07 d$ & $2054.77 d$ & $11.320 \mathrm{f}$ & $12.160 \mathrm{f}$ & $122.476700 \mathrm{~b}$ & $116.83330 \mathrm{a}$ \\
\hline & & $\mathrm{V}_{2}$ & $1298.33 \mathrm{e}$ & $1882.57 \mathrm{e}$ & $12.790 \mathrm{e}$ & $13.730 \mathrm{e}$ & $108.660000 \mathrm{e}$ & $102.88670 \mathrm{e}$ \\
\hline & & $\mathrm{V}_{3}$ & $2454.23 \mathrm{a}$ & $3558.63 \mathrm{a}$ & $26.160 \mathrm{~d}$ & $28.090 \mathrm{~d}$ & $115.540000 \mathrm{~d}$ & $108.78000 \mathrm{~d}$ \\
\hline & & $\mathrm{V}_{4}$ & $1321.47 \mathrm{e}$ & $1916.13 \mathrm{e}$ & $28.750 \mathrm{c}$ & $30.880 \mathrm{c}$ & $120.403300 \mathrm{bc}$ & $114.02330 \mathrm{~b}$ \\
\hline & & $\mathrm{V}_{5}$ & $1880.40 \mathrm{~b}$ & $2726.60 \mathrm{~b}$ & $36.150 \mathrm{a}$ & $38.830 \mathrm{a}$ & $126.430000 \mathrm{a}$ & $118.82000 \mathrm{a}$ \\
\hline & & $\mathrm{V}_{6}$ & $1519.40 \mathrm{c}$ & $2203.13 c$ & $28.800 \mathrm{~b}$ & $30.930 \mathrm{~b}$ & $118.676700 \mathrm{c}$ & $111.84000 \mathrm{c}$ \\
\hline
\end{tabular}

For a given means within each column of each section followed by the same letter are not significantly different $(\mathrm{p}<0.05)$

Plants under water deficit stress showed a significant increase in SOD, CAT and GPX activities in leaves compared with control plants (Table 2). In water deficit stress conditions Hyola330 with product of
Antioxidant enzymes could increase yield and harvest index. Application of super absorbent to stressed plants decreased the Antioxidant enzymes activity in the leaves, that this conditions Option500 increased product 
of Antioxidant enzymes. In this context, plants with higher levels of antioxidants, either constitutive or induced, have been reported to possess SODeater resistance to these stress conditions and higher yield and dry matter allocation to SODain filling process i.e., harvest index (Table 1 and 2$)^{[19,50]} \cdot \mathrm{H}_{2} \mathrm{O}_{2}$ can be removed using the ascorbate-glutathione cycle [ascorbic acid (ASA)-GSH cycle] which APX and SOD are the key enzymes in this cycle ${ }^{[38]}$. In the present study, water stress and lack of super absorbent led to a significant increase in the APX compared to the respective controls, although there were some variations among canola cultivars and super absorbent (Table 1 and 2). The diverse responses of the APX and SOD enzyme activities in the plants subjected to saline conditions suggest that oxidative stress is an important component of drought stress ${ }^{[51]}$. These results are in agreement with those of Stepien and Klobus ${ }^{[51]}$, who have propounded that the APX and SOD and CAT action suggests that the more active ascorbate-glutathione cycle may be related to the development of relatively higher drought tolerance in maize. The constitutive and the drought-induced APX and SOD activities were remarkably higher in the cultivars SOD at 35 compared to $25^{\circ} \mathrm{C}$. These results may point out that the lack of superabsorbent provokes antioxidant enzyme responses (Table 2 and 3). Our results are consistent with other parameters of these six canola cultivars i.e., stress caused a decline in the $\mathrm{K}+/ \mathrm{Na}+$ ratio, plant height, fresh and dry biomass of the shoot and an increase in the relative leakage ratio and the contents of proline and $\mathrm{Na}+{ }^{[16]}$. POD activity decreased considerably upon drought treatments under both superabsorbents levels in all cultivars (Table 2). Drought and superabsorbent treatment increased the activity in this canola cultivar by 1.5 fold. Conversely, Ben Amor et $a l^{[7]}$ found that peroxidase activity in the Cakile maritime increased SODadually with time and with increasing Drought

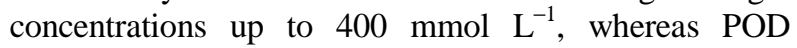
unexpectedly started to decrease in plants treated with 400 mmol $\mathrm{L}^{-1}$ Drought.. Our results suggest that drought stress directly or indirectly leads to production of oxygen radicals, which results in increased lipid peroxidation and oxidative stress in the plant. Drought stress may also lead to stomata closure, which reduces $\mathrm{CO}_{2}$ availability in the leaves and inhibits carbon fixation. This exposes the chloroplast to excessive excitation energy, which in turn could increase the generation of free radicals and induce oxidative stress ${ }^{[26]}$. The canola plant which is considered moderately drought tolerant $^{[43]}$ might have inadequate ROS scavenging system, in addition to other tolerance mechanisms, to cope with stress. The increase in SOD activity was reported in tolerance basmati rice variety ${ }^{[52]}$. In our study, super absorbent polymer decreased the activity of these enzymes maybe by elimination of free radicals.

Table 3: Effects of Irrigation Regimes (IR) and super absorbent concentration (SU) and variety (VA) on yield and harvest index and antioxidant enzymes in canola in 2007 and 2008

\begin{tabular}{|c|c|c|c|c|c|c|}
\hline & & & SOD $\left(\mathrm{u} \mathrm{mg}^{-1}\right.$ protein) 2007 & SOD $\left(\mathrm{u} \mathrm{mg}^{-1}\right.$ protein $) 2008$ & GPX (u mg-1 protein) 2007 & GPX $\left(\mathrm{u} \mathrm{mg}^{-1}\right.$ protein $) 2008$ \\
\hline$\overline{\mathrm{IR}}$ & SU & VA & & & & \\
\hline \multirow[t]{12}{*}{$\mathrm{I}_{1}$} & $\mathrm{~S}_{1}$ & $\mathrm{~V}_{1}$ & $1363.00 \mathrm{bc}$ & $1260.000 \mathrm{c}$ & $16.31330 \mathrm{c}$ & $15.93670 \mathrm{c}$ \\
\hline & & $\mathrm{V}_{2}$ & $1340.33 \mathrm{~cd}$ & $1235.000 \mathrm{~d}$ & $16.44670 \mathrm{c}$ & $15.52330 \mathrm{c}$ \\
\hline & & $\mathrm{V}_{3}$ & $1313.67 \mathrm{de}$ & $1203.333 \mathrm{e}$ & $15.93670 \mathrm{c}$ & $15.49670 \mathrm{c}$ \\
\hline & & $\mathrm{V}_{4}$ & $1382.67 \mathrm{ab}$ & $1271.000 \mathrm{~b}$ & $17.40670 \mathrm{~b}$ & $16.87330 \mathrm{~b}$ \\
\hline & & $\mathrm{V}_{5}$ & $1413.670 \mathrm{a}$ & $1307.667 \mathrm{a}$ & $18.22330 \mathrm{a}$ & $17.82670 \mathrm{a}$ \\
\hline & & $\mathrm{V}_{6}$ & $1296.330 \mathrm{e}$ & $1192.000 \mathrm{f}$ & $17.24330 \mathrm{~b}$ & $16.56670 \mathrm{~b}$ \\
\hline & $\mathrm{S}_{2}$ & $\mathrm{~V}_{1}$ & $1313.000 \mathrm{e}$ & $1194.000 \mathrm{~d}$ & $15.08330 \mathrm{~d}$ & $14.92667 \mathrm{c}$ \\
\hline & & $\mathrm{V}_{2}$ & $1395.000 \mathrm{a}$ & $1271.000 \mathrm{a}$ & $15.77330 \mathrm{~b}$ & $15.32000 \mathrm{~b}$ \\
\hline & & $\mathrm{V}_{3}$ & $1387.000 \mathrm{~b}$ & $1268.000 \mathrm{a}$ & $15.44000 \mathrm{c}$ & $14.88000 \mathrm{c}$ \\
\hline & & $\mathrm{V}_{4}$ & $1393.000 \mathrm{a}$ & $1264.000 \mathrm{a}$ & $16.18000 \mathrm{a}$ & $15.86333 a$ \\
\hline & & $\mathrm{V}_{5}$ & $1348.000 \mathrm{c}$ & $1231.333 b$ & $15.5800 \mathrm{bc}$ & $15.68667 \mathrm{a}$ \\
\hline & & $\mathrm{V}_{6}$ & $1331.333 d$ & $1212.333 c$ & $14.95330 \mathrm{~d}$ & $15.40000 \mathrm{~b}$ \\
\hline \multirow[t]{12}{*}{$\mathrm{I}_{2}$} & $\mathrm{~S}_{1}$ & $\mathrm{~V}_{1}$ & $1846.000 \mathrm{~b}$ & $1605.000 \mathrm{~d}$ & $26.35000 \mathrm{c}$ & $25.76330 \mathrm{c}$ \\
\hline & & $\mathrm{V}_{2}$ & $1610.300 \mathrm{~b}$ & $1474.000 \mathrm{f}$ & $22.31330 \mathrm{f}$ & $21.48670 f$ \\
\hline & & $\mathrm{V}_{3}$ & $1702.000 \mathrm{~b}$ & $1561.333 \mathrm{e}$ & $23.18000 \mathrm{e}$ & $22.46330 \mathrm{e}$ \\
\hline & & $\mathrm{V}_{4}$ & $1966.300 \mathrm{~b}$ & $2152.667 \mathrm{~b}$ & $29.18330 \mathrm{~b}$ & $28.14330 \mathrm{~b}$ \\
\hline & & $\mathrm{V}_{5}$ & $2408.000 \mathrm{a}$ & $2263.000 \mathrm{a}$ & $32.54670 \mathrm{a}$ & $30.93670 \mathrm{a}$ \\
\hline & & $\mathrm{V}_{6}$ & $1794.700 \mathrm{~b}$ & $1635.000 \mathrm{c}$ & $24.87670 \mathrm{~d}$ & $23.17670 \mathrm{~d}$ \\
\hline & $\mathrm{S}_{2}$ & $\mathrm{~V}_{1}$ & $1657.333 \mathrm{c}$ & $1532.000 \mathrm{c}$ & $21.19670 \mathrm{c}$ & $20.06667 \mathrm{c}$ \\
\hline & & $\mathrm{V}_{2}$ & $1429.000 \mathrm{f}$ & $1297.333 f$ & $18.18000 \mathrm{f}$ & $17.42667 f$ \\
\hline & & $\mathrm{V}_{3}$ & $1508.667 \mathrm{e}$ & $1394.000 \mathrm{e}$ & $19.57000 \mathrm{e}$ & $18.51000 \mathrm{e}$ \\
\hline & & $\mathrm{V}_{4}$ & $2096.333 b$ & $1971.333 b$ & $23.65670 \mathrm{~b}$ & $22.60667 \mathrm{~b}$ \\
\hline & & $\mathrm{V}_{5}$ & $2211.000 \mathrm{a}$ & $2085.000 \mathrm{a}$ & $26.62670 \mathrm{a}$ & $25.76667 \mathrm{a}$ \\
\hline & & $\mathrm{V}_{6}$ & $1562.667 \mathrm{~d}$ & $1445.667 \mathrm{~d}$ & $20.07670 \mathrm{~d}$ & $19.36333 d$ \\
\hline
\end{tabular}

For a given means within each column of each section followed by the same letter are not significantly different $(\mathrm{p}<0.05)$ 
Application of super absorbent polymer could reserve different amounts of water in itself and so increases the soil ability of water storing and preserving and at last in water deficiency, produce plant water need and approve its growth. Thus in drought stress application of super absorbent caused yield and harvest index. Results are in comparison with Padman studies ${ }^{[45]}$, based on increasing the seed yield in improved treatment with this substance. Because, for inducing high yield, adequate water is necessary, these substances result is better and more effective use of water and nutrition with increasing the available water for plant and at least increase the yield. In notification to this harvest index, that is actually the proportion of seed yield to biologic yield, with better access of plant to humidity and nutrition by super absorbent, rate of both qualities increases and at last the harvest index rate increases The result of decrease in harvest index during stress is compatible with Turk et al. ${ }^{[51]}$ result. They concluded that due to stress and water deficiency certainly the transmission of photosynthetic substances to shoot organs decrease and in the end yield components reduce. Indeed with reduction of these components the rate of harvest index decreases.

\section{DISCUSSION}

Canola yield is to a very large degree a result of the interaction of nitrogen and carbon acquisition throughout the life cycle and a partitioning of these resources to seed production. Thus, effects of irrigation regimes and reservoir of soil water and micronutrients to plants on successful acquisition of these resources in different genotypes may be useful as tools for improved yield and water use efficiency. The stress treatments decrease the number of days required for canola plants to reach $50 \%$ flowering or maturity by an average of 47 days compared with the unstressed control. It has been reported in faba bean (Vicia faba L.) ${ }^{[40]}$. Acceleration of flowering and/or maturity probably contributed to reduce the impact of drought stress in canola varieties. The decrease in yield and yield components in different safflower genotypes due to water deficiency has also been reported by other researchers $^{[33,34,54]}$. Anyia and Herzog ${ }^{[2]}$ indicated that water deficit caused between 11 and more than $40 \%$ reduction of biomass across the genotypes of cowpea (Vigna unguiculata (L.) Walp.) due to decline in leaf gas exchange and leaf area. The increase in resistance to drought stress is associated with the antioxidant activity. According to these results it can be suggested that usage of super absorbent polymer can reduce the harmful effects of ROS and improves plant resistance. Plants resort to a range of distinct acclimation strategies in response to abiotic environmental stresses such as drought, dehydration, cold, heat and excessive osmotic pressure $^{[42]}$. Drought stress is an intricate phenomenon which includes osmotic stress, specific ion effect, nutrient deficiency thereby affecting various physiological and biochemical mechanisms associated with plant resisistance development ${ }^{[46]}$. It has been suggested that salinity causes oxidative stress by inhibition of the $\mathrm{CO}_{2}$ assimilation, exposing chloroplasts to excessive excitation energy, which in turn increases the generation of ROS from triplet chlorophyll $^{[25]}$ Several researchers have suggested that drought tolerance is often correlated with a more efficient antioxidative system ${ }^{[6,11,19,25]}$. Some canola cultivars increased their enzyme activities as a consequence of stress, however, these responses might not be enough to overcome the detrimental effects of long-term stress or to allow survival of the plants as it was observed that all canola cultivars lost their vitality under the highest stressful conditions at the end of experiment. Foyer et al. ${ }^{[23]}$ proposed that the absence of a rapid increase in the level of transcripts of the antioxidant enzymes could be related to the role of ROS in signal transduction. This difference between transcript levels and enzyme activities during Drought treatment may result from a higher turnover of these enzymes and/or an increase of their inactivation by $\mathrm{H}_{2} \mathrm{O}_{2}{ }^{[47]}$. Abiotic stress, such as drought stress cause molecular damage to plant cells either directly or indirectly through the formation of ROS. In the present study, the plants exposed to drought showed a significant increase in SOD, CAT and GPX activity in the leaves. The enzymes assayed are scavengers of free radical species. SOD converts one form of $\operatorname{ROS}\left(\mathrm{O}_{2}{ }^{-}\right)$to another equally toxic one $\left(\mathrm{H}_{2} \mathrm{O}_{2}\right)$. Hydrogen peroxide is converted to oxygen and water by CAT and POX, which use ascorbate as the hydrogen donor ${ }^{[30]}$. In conclusion, the results of the present study clearly showed that there was differential accumulation of $\mathrm{H}_{2} \mathrm{O}_{2}$ as well as genotypic variations in $\mathrm{H}_{2} \mathrm{O}_{2}$-scavenging enzymes in canola cultivars SODown under different drought stress and high superabsorbent conditions.

\section{CONCLUSION}

In conclusion this study has shown that application of super absorbent polymer can increase the survival capacity of canola plants under conditions of drought stress. 


\section{REFERENCES}

1. Alscher, R.G., J.L. Donahue and C.L. Cramer, 1997. Reactive oxygen species and antioxidants: Relationships in green cells. Physiol. Plant, 100: 224-233. DOI: 10.1034/j.13993054.1997.1000203.x

2. Anyia, A.O. and H. Herzog, 2004. Water-use efficiency, leaf area and leaf gas exchange of cowpeas under mid-season drought. Eur. J. Agron, 20: 327-339. http://dialnet.unirioja.es/servlet/articulo?codigo $=800111$

3. Asada, K., 1999. The water-water cycle in chloroplasts: Scavenging of active oxygens and dissipation of excess photons. Annu. Rev. Plant Physiol. Plant Mol. Biol., 50: 601-639. http://www.ncbi.nlm.nih.gov/pubmed/15012221

4. Ashraf, M. and McNeilly, 2004. Salinity tolerance in some Brassica oilseed. Crit. Rev. Plant Sci., 23: $154-174$.

http://cat.inist.fr/?aModele=afficheN\&cpsidt=1564 4238

5. Ashraf, M. and P.J.C. Harris, 2004. Potential biochemical indicators of salinity tolerance in plants. Plant Sci., 166: 3-16. http://dwkx.hzau.edu.cn/kech/ssyy/qysd/njsl/21.pdf

6. Bartoli, C.G., M. Simontacchi, E. Tambussi, J. Beltrano, E. Montald and S. Puntarulo, 1999. Drought and watering-dependent oxidative stress: Effect on antioxidant content in Triticum aestivum L. leaves. J. Exp. Bot., 50: 375-383. http://jxb.oxfordjournals.org/cgi/content/abstract/5 0/332/373

7. Blum, A., 1996. Crop responses to drought and the interpretation of adaptation. Plant Growth Regul., 20: 35-148. DOI: $10.1007 / \mathrm{BF} 00024010$

8. Ben Amor, N., A. Jimenez, W. Megdiche, M. Lundqvist, F. Sevilla and C. Abdelly, 2007. Kinetics of the anti-oxidant response to salinity in the halophyte Cakile maritime. J. Integr. Plant Biol., 49: 982-992. DOI: 10.1111/j.1672-9072.2007.00491.x

9. Cakmak, I. and W. Horst, 1991. Effect of aluminum on lipid peroxidation, superoxide dismutase, catalase and peroxidase activities in root tip of soybean (glysin max). Plant Physiol., 83: 463-468. DOI: 10.1111/j.13993054.1991.tb00121.x

10. Chaves, M.M., J.P. Maroco and J.S. Pereira, 2003. Understanding plant responses to drought: From genes to the whole plant. Funct. Plant Biol., 30: 239-264.

http://cat.inist.fr/?aModele $=$ afficheN\&cpsidt $=1460$ 3446
11. Hong, P.C., Z.S. Jun, G.Z. Zhong and W.W. Bao-Shan, 2005. NaCl treatment markedly enhances $\mathrm{H}_{2} \mathrm{O}_{2}$-scavenging system in leaves of halophyte Suaeda salsa. Physiol. Plant, 125: 490-499. DOI: $10.1111 /$ j.13993054.2005.00585.x

12. Cicek, N. and H. Çakırlar, 2008. Effects of salt stress on some physiological and photosynthetic parameters at three different temperatures in six soya bean (Glycine $\max$ L. Merr.) cultivars. J. Agron. Crop Sci., 194: 34-46. http://cat.inist.fr/?aModele $=$ afficheN\&cpsidt $=2013$ 9672

13. De Boot, M., 1990. Application of Polymeric Substances as Physical Soil Conditioners. In: Soil Colloids and their Association in Soil Aggregates, De Boodt, M. et al. (Ed.). Planum Publishing Corporation, London, New York, ISBN: 0306434199, pp: 580-592.

14. Demiral, T. and I. Turkan, 2005. Comparative lipid peroxidation, antioxidant defense systems and proline content in roots of two rice cultivars differing in salt tolerance. Environ. Exp. Bot., 53: 247-257.

http://cat.inist.fr/?aModele $=$ afficheN\&cpsidt $=1671$ 0559

15. Dionisio-Sese, M.L. and S. Tobita, 1998. Antioxidant responses of rice seedlings to salinity stress. Plant $\quad$ Sci., 135: 1-9. http://cat.inist.fr/?aModele $=$ afficheN\&cpsidt $=2362$ 962

16. Foyer, C.H. and B. Halliwell, 1976. The presence of glutathione and glutathione reductase in chloroplasts: A proposed role in ascorbic acid metabolism. Planta, 133: 21-25. DOI: 10.1007/BF00386001

17. Foyer, C.H. and G. Noctor, 2003. Redox sensing and signalling associated with reactive oxygen in chloroplasts, peroisomes and mitochondria. Physiol. Plant, 119: 355-364. http://cat.inist.fr/?aModele $=$ afficheN\&cpsidt $=1520$ 7483

18. Foyer, C.H., M. Lelandais and K.J. Kunert, 1994. Photooxidative stress in plants. Physiol. Plant, 92: 696-717. http://cat.inist.fr/?aModele $=$ afficheN\&cpsidt=3339 390

19. Ghanati, F., A. Morita and H. Yokota, 2002. Induction of suberin and increase of liginin content by exess boron in Tabacco cell. Soil Sci. Plant Nutr., $\quad$ 48: 357-364. http://direct.bl.uk/bld/PlaceOrder.do?UIN=115476 $877 \&$ ETOC $=$ RN\&from $=$ searchengine 
20. Gossett, D.R., E.P. Millhollon, M.C. Lucas, S.W. Banks and M.M. Marney, 1994. The effects of $\mathrm{NaCl}$ on antioxidant enzyme activities in callus tissue of salt-tolerant and salt sensitive cultivars (Gossypium hirsutum L.). Plant Cell Rep., 13: 498-503. http://cat.inist.fr/?aModele $=$ afficheN\&cpsidt $=4129521$

21. Gossett, D.R., E.P. Millhollon and M.C. Lucas, 1994. Antioxidant response to $\mathrm{NaCl}$ stress in salttolerant and salt-sensitive cultivars of cotton. Crop Sci., 34: 706-714. http://cat.inist.fr/?aModele $=$ afficheN\&cpsidt $=4148223$

22. Hernandez, J.A., F.J. Corpas, M. Gomez, L.A. Del Rio and F. Sevilla, 1993. Salt-induced oxidative stress mediated by activated oxygen species in pea leaf mitochondria. Physiol. Plant, 89:103-110. http://cat.inist.fr/?aModele $=$ afficheN\&cpsidt $=3876985$

23. Hernandez, J.A., A. Campillo, A. Jimenez, J.J. Alarcon and F. Sevilla, 1999. Response of antioxidant systems and leaf water relations to $\mathrm{NaCl}$ stress in pea plants. New Phytol., 141: 241-251. http://cat.inist.fr/?aModele=afficheN\&cpsidt=1711035

24. Hernandez, J.A., A. Jimenez, P. Mullineaux and F. Sevilla, 2000. Tolerance of pea (Pisum sativum L.) to long-term salt stress is associated with induction of antioxidant defenses. Plant Cell Environ., 23: 853-862. http://cat.inist.fr/?aModele $=$ afficheN\&cpsidt $=1460306$

25. Hegedus, A., S. Erdei and G. Horvath, 2001. Comparative studies of $\mathrm{H}_{2} \mathrm{O}_{2}$ detoxifying enzymes in green and greening barley seedlings under cadmium stress. Plant Sci., 160: 1085-1093. DOI: 10.1016/S0168-9452(01)00330-2

26. Johnson, S.M., S.J. Doherty and R.R.D. Croy, 2003. Biphasic superoxide generation in potato tubers: A self amplifying response to stress. Plant Physiol., 13: 1440-1449. http://www.plantphysiol.org/cgi/content/abstract/1 $31 / 3 / 1440$

27. Johnson, M.S. and R.T. Leah, 1990. Effect of superabsorbent polyacrylamide on efficacy of water use by crop seedlings. J. Sci. Food Agric., 52: 431-434. DOI: 10.1002/jsfa.2740520316

28. Kar, G., A. Kumar and M. Martha, 2007. Water use efficiency and crop coefficients of dry season oilseed crops. Agric. Water Manage., 87: 73-82. DOI: 10.1016/J.AGWAT.2006.06.002

29. Lovelli, S., M. Perniola, A. Ferrara and T. Di Tommaso, 2007. Yield response factor to water (Ky) and water use efficiency of Carthamus tinctorius L. and Solanum melongena L. Agric. Water Manage., 92: 73-80. http://ideas.repec.org/a/eee/agiwat/v92y2007i12p73-80.html
30. Maldonado-Rodriguez, R., 1999-2002. Biolyzer Software. Laboratory of Bioenergentics, University of Geneva, Switzerland, pp: 457.

31. Mansour, M.M.F., K.H.A. Salama, F.Z.M. Ali and A.F. Abou Hadid, 2005. Cell and plant responses to $\mathrm{NaCl}$ in Zea mays L. cultivars differing in salt tolerance. Gen. Applied Plant Physiol., 31: 29-41. http://www.bio21.bas.bg/ipp/gapbfiles/v-31/05_12_29-41.pdf

32. Meloni, D.A., M.A. Oliva, C.A. Martinez and J. Cambraia, 2003. Photosynthesis and activity of superoxide dismutase, peroxidase and glutathione reductase in cotton under salt stress. Environ. Exp. Bot., 49: 69-76. DOI: 10.1016/S00988472(02)00058-8

33. Mittler, R., 2002. Oxidative stress, antioxidants and stress tolerance. Trends Plant Sci., 7: 405-410. http://www.ncbi.nlm.nih.gov/pubmed/12234732

34. Noctor, G. and C.H. Foyer, 1998. Ascorbate and glutathione: Keeping active oxygen under control. Ann. Rev. Plant Physiol. Plant Mol. Biol., 49: 249-279. http://www.ncbi.nlm.nih.gov/pubmed/15012235

35. Munns, R., 2002. Comparative physiology of salt and water stress. Plant Cell Environ., 25: 239-250. DOI: 10.1046/j.0016-8025.2001.00808.x

36. Mwanamwenge, J., S.P. Loss, K.H.M. Siddique and P.S. Cocks, 1999. Effect of water stress during floral initiation, flowering and podding on the growth and yield of faba bean (Vicia faba L.). Eur. J. Agron., 11: 1-11. DOI: 10.1016/S11610301(99)00003-9

37. Ouchi, S., A. Nishikawa and E. Kameda, 1990. Soil-improving effect of a super-water-absorbentpolymer II. Evaporation, leaching of salts and growth of vegetables. Jap. J. Soil Sci. Plant Nutr., 61: 606-613.

http://www.fao.org/agris/search/display.do?f=./199 4/v2007/JP9306919.xml;JP9306919

38. Pasternak, T., V. Rudas, G. Potters and M.A.K. Jansen, 2005. Morphogenic effects of abiotic stress: Reorientation of growth in Arabidopsis thaliana seedlings. Environ. Exp. Bot., 53: 299-314. http://cat.inist.fr/?aModele $=$ afficheN\&cpsidt $=16710563$

39. Pitman, M.G. and A. Lauchli, 2002. Global Impact of Salinity and Agricultural Ecosystems. In: Salinity: Environment-Plants Molecules, Lauchli, A. and V. Luttge (Eds.). Kluwer, Netherlands, ISBN: 1402004923, pp: 3-20.

40. Reddy, A.R., K.V. Chaitanya and M.M. Vivekanandan, 2004. Drought-induced responses of photosynthesis and antioxidant metabolism in higher plants. J. Plant Physiol., 161: 1189-1202. http://www.ncbi.nlm.nih.gov/pubmed/15602811 
41. Padman, D.R., B.L. Porwal and J.C. Ptel, 1994. Effect of Levels of Irrigation Nitrogen and jalas hakti on growth and yield Indian mustard. Ind. J. Agron., $\quad 39$ : 599-603. DOI: 09.1102/jsfb.2545857854

42. Sairam, R.K., K.V. Rao and G.C. Srivastavam, 2002. Differential response of wheat genotypes to long term salinity stress in relation to oxidative stress, antioxidant activity and osmolyte concentration. Plant Sci., 163: 1037-1046. http://cat.inist.fr/?aModele $=$ afficheN\&cpsidt $=1400$ 9786

43. Scandalios, J.G., 1993. Oxygen stress and superoxide dismutases. Plant Physiol., 101: 7-12. http://www.pubmedcentral.nih.gov/articlerender.fc gi?artid=158641

44. Shalata, A., V. Mittova, M. Volokita, M. Guy and M. Tal, 2001. Response of the cultivated tomato and its wild salt-tolerant relative Lycopersicon pennellii to salt-dependent oxidative stress: The root antioxidative system. Physiol. Plant, 112: 487-494. DOI: 10.1034/j.1399-3054.2001.1120405.x

45. Sreenivasulu, N., B. Grimm, U. Wobus and W. Weschke, 2000. Differential response of antioxidant compounds to salinity stress in salttolerant and salt-sensitive seedlings of foxtail millet (Setaria italica). Physiol. Plant, 109: 435-442. http://cat.inist.fr/?aModele $=$ afficheN\&cpsidt $=1498$ 325

46. Stepien, P. and G. Klobus, 2005. Antioxidant defense in the leaves of $\mathrm{C}_{3}$ and $\mathrm{C}_{4}$ plants under salinity stress. Physiol. Plant, 125: 31-40. http://cat.inist.fr/?aModele $=$ afficheN\&cpsidt $=1706$ 3393

47. Singh, M.P., D.K. Singh and M. Rai, 2007. Assessment of groeth, Physiological and biochemical parameters and activities of antioxidant enzymes in salinity tolerant and sensitive basmati rice varieties. J. Agron. Crop Sci., 193: 398-412. DOI: 10.1111/j.1439037X.2007.00267.x
48. Sinha, S.K., R. Khanna-Chopre, P.K. Aggarwal, G.S. Chaturvedi and K.R. Koundal, 1982. Effect of Drought on Shoot Growth: Significance of Metabolism to Growth and Yield. In: Drought Resistance in Crop with Emphasis on Rice, IRRI, Manila, Philippines, ISBN: 5784585099, pp: 153-169.

49. Steel, R.G. and J.H. Torrie, 1980. Principals and Procedures of Statistics: A Biometric Approach. MCGraw-Hill, New York, USA., ISBN: 2587584587, pp: 421.

50. Tsugane, K., K. Koboyashi, Y. Niwa, Y. Ohba, K. Wada and H. Koboyashi, 1999. A recessive Arabidobsis mutant that grows photoautotrophically under salt stress shows enhanced active oxygen detoxification. Plant Cell, 11: 1195-1206. http://www.pubmedcentral.nih.gov/articlerender.fc gi?artid=144266

51. Turk, K.J., A.E. Hall and G.W. Asbell, 1980. Drought adaption of cowpea. I. influence of drought on seed yield. Agron. J., 72: 413-420. http://agron.scijournals.org/cgi/content/abstract/72/ $3 / 413$

52. Wang, S.Y., H. Jiao and M. Faust, 1991. Changes in ascorbate, glutathione and related enzyme activities during thiodiazuron-induced bud break of apple. Plant Physiol., 82: 231-236. DOI: 10.1111/j.1399-3054.1991.tb00086.x

53. Zaman, A. and P.K. Das, 1991. Effect of irrigation and nitrogen on yield and quality of safflower. Indian J. Agron., 36: 177-179.

54. Zhange, J.X. and M.B. Kirkham, 1995. Water relation of water-stressed, split-root $\mathrm{C}_{4}$ (Sorghum bicolor, Poaceae) and $\mathrm{C}_{3}$ (Helianthus annuus; Asteraceae) plants. Am. J. Bot., 82: 1220-1229. http://www.jstor.org/stable/2446244 